\title{
Agrippina as prima donna: The reception of Agrippina, mother of Nero, in Handel's opera Agrippina
}

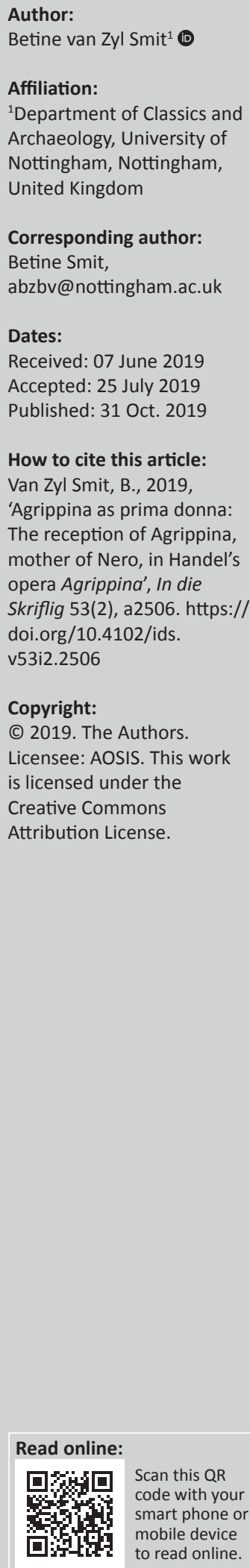

This article examines the way in which Agrippina, the mother of the emperor Nero, is depicted in Handel's opera Agrippina. The opera's libretto, written by Cardinal Vincenzo Grimani, draws upon the historical information in Suetonius' biography of Claudius and upon the events described in books 12 to 14 of Tacitus' Annals. The article shows how Grimani juggled the chronology, events and relationships among the characters to omit the tragic and gruesome details, and to create a satirical comedy of succession.

Keywords: Georg Friedrich Handel; Vincenzo Grimani; Agrippina Opera; Emperor Nero; Emperor Claudius; Empress Agrippina; Suetonius' Biography of Claudius; Tacitus Annals 12-14; Opera Libretto; Poppaea Sabina; Otho.

\section{Introduction}

The relationships and events at the heart of the Roman Empire in the middle years of the 1st century $\mathrm{AD}^{1}$ contain plenty of drama and intrigue. The accounts of Tacitus in his Annals and in the biographies of the emperors Claudius and Nero by Suetonius, depict a series of marriages and murders that would make material for the most lurid fiction. Such events occurred at the courts of Claudius (41-54) and Nero (54-64). This tale of ambition, love and jealousy within the imperial family provides material similar to that of the myths that are the subject matter of many Greek tragedies. At least one Roman dramatist thought so. We do not know the name of this tragedian who used the historical background and characters at Nero's court as the basis for a plot for his play, Octavia. This tragedy is the sole surviving example of a fabula togata or tragedy set in Roman context and dress.

Early opera similarly drew from this period in Roman history and provides a number of examples of works with activities at the Neronian court as the storyline for their plots. The earliest opera to make use of historical characters for its intrigues, is Claudio Monteverdi's L'incoronazione di Poppea, which was first produced in Venice in 1643. It overlaps to some extent with the Octavia in portraying the adulterous love affair between the emperor, Nero, and his mistress, Poppaea, married to Otho. It even retains Seneca as one of the characters, but also introduces fictive characters such as Drusilla - a young woman in love with Otho. The opera ends with the marriage of Nero and Poppaea, and her coronation as empress as the title indicates. The librettist, Giovanni Businello, did not significantly alter historical facts to be found in the Annals of Tacitus or the life of Nero as recounted by the biographer Suetonius. ${ }^{2}$

This reasonably faithful approach to the accounts of the Roman authors is very different to that adopted by the librettist, Vincenzo Grimani, who wrote the words for Georg Friedrich Handel's opera Agrippina, which had its premiere also in Venice in 1709 (DVD - Fisbach 2004). This article will examine the way in which the eponymous heroine of Handel's opera is depicted. It will show in which respects her role and character are derived from her portrayal in the works of Tacitus and Suetonius, and how they have been altered to create the arch-manipulator who is the central figure in this roller coaster satirical comedy. This new interpretation of Agrippina is what is termed her 'reception' in the opera. It examines how the historical features, detailed by Tacitus and Suetonius, have been used as the basis for the creation of an altered character in a different context.

This article concentrates on the words of the libretto rather than the music. I am conscious that more extensive analysis of the score will enhance the impact of the character traits evident from a 1.All dates in this article are AD.

2.Boyle (2008: Ixxxiv-Ixxxvi) discusses Busenello's libretto as reception of Octavia and notes that the opera libretto even has verbal debts to the tragedy. He lists a number of other late 17th-and early 18th-century operas which deal with Nero and the historical events and figures of Octavia; among them Grimani and Handel's Agrippina. 
study of the libretto, but his would entail a far longer study than the present one. ${ }^{3}$ Thus, my discussion is based on Cardinal Vincenzo Grimani's libretto for Handel's opera, although the work bears the composer's name. Agrippina was Handel's second opera, composed while he was coming to the end of a sojourn in Italy. According to contemporary accounts, it was met with great acclaim. Scholars ascribe its success not only to the music, but also to Grimani's libretto, which in the words of a recent editor, has 'a tightly drawn plot, sharply etched characters, and a considerable variety of human emotions' (Sawyer 2013:XXI).

Grimani's sources were books $12-14$ of Tacitus' Annals and Suetonius' life of Claudius. He did not make use of Dio's account. Grimani took the historical characters and preserved some of the relationships among them, but allowed himself a free hand with chronology and gave his imagination considerable rein. The dark deeds and murders, detailed in the pages of the Roman historians, could easily have resulted in a violent melodrama or stark tragedy, but Grimani opted for 'an anti-heroic comedy of a type popular throughout the seventeenth century in Italy' (Dean \& Knapp 1987:118).

Agrippina undoubtedly played a central role during the reign of both her husband and uncle, Claudius, and that of her son, Nero. Marianne Dircksen (1999) summarised her role succinctly in the abstract of her article on the depiction of Agrippina:

Ancient historians characterised Agrippina as an exceptionally strong-willed woman who had an immense influence on the Roman Empire while she was the wife of the emperor Claudius and mother of his successor, Nero. (p. 119)

Agrippina had the unique distinction of being the sister, wife and mother of emperors of Rome. As a woman who, through bold intrigues and crimes, became powerful in a time when women had no official political power, and because of her gruesome end, she has provoked strong reactions from historians. These are detailed by Barrett in Agrippina - Sex, power and politics in the Early Empire, his study of her historical role. Barrett (1996:XX11--XXIII) comes to a balanced conclusion that she actually contributed to stabilising the Claudian regime as well as being, at least partly, instrumental in ensuring good administration during the first years of Nero's rule.

Grimani, however, focuses on her overriding ambition to secure the position of emperor for her son, Nero. Nevertheless, the operatic Agrippina is a complex character. As she voices her feelings and plans herself, the audience are shown a nuanced personality, less grim than the one presented by the historians who mostly describe her actions and do not give her, her own voice. ${ }^{4}$ Grimani's Agrippina is cunning and determined, but also takes obvious delight in her schemes

3.For an analysis of the music and the arias, see the detailed discussion in Dean and Knapp (1987:119-128).

4.Only in two instances does Tacitus present direct speech by Agrippina: in Ann. 13.21, and in her death scene, Ann. 14.8. and in playing off different characters against each other. The audience are always aware of her plans and share her tension about their success.

The driving force of the opera's plot is Agrippina's determination that her son should become ruler of the Roman world and that she will be the power behind the throne. This underlying motive is apparent in Tacitus' account. In fact, he notes that her marriage to Claudius had already given her access to the levers of control: versa ex eo civitas et cuncta feminae oboediebant (because of that [the marriage], the state was transformed and all obeyed a woman) (Annals 12.7). Tacitus also notes that, at the start of Nero's reign, Agrippina even tried to exert control more openly than during Claudius' regime where her manipulation was not on public show. The historian recounts that she listened to senate meetings from behind a curtain and even tried to mount the tribunal to sit beside Nero when he was receiving a foreign delegation. (Annals 13). Tacitus also reports that among the 'crimes' Nero attributed to his mother in a letter to the senate after her death, were that she had hoped for consortium imperii [joint rule] and that she wanted not only the praetorian guard, but also the senate and people to swear an oath of loyalty to her, a woman (Annals 14.11). It would have been constitutionally impossible for a woman to exercise these powers, but Nero's allegations clearly were meant to reflect the outrageous dimensions of the ambitions ascribed to Agrippina. This lust for power appears in the opera both in the libretto ${ }^{5}$ and the stage directions, which have Agrippina mounting the throne jointly with Nero at the first attempt to proclaim him as emperor.

The historical characters retained in the opera are Agrippina, Claudius, Nero, Poppaea, Otho and the freedmen Narcissus and Pallas. ${ }^{6}$ The only invented character is Lesbo, a servant of Claudius who acts as his go-between. There is no chorus, although at points in the opera all the characters join together in a chorus. A summary of the historical events and relationships between and among the characters is necessary to make clear the ways in which Grimani adapted them. In brief, the pages of Tacitus' Annals and Suetonius' biography of Claudius relate how Agrippina succeeded in marrying the emperor after his third wife, Messalina, was executed in 48. Agrippina was determined that her son by her first husband, Gnaeus Domitius Ahenobarbus, should become emperor. She managed to persuade Claudius to adopt him in 50 and give precedence to him above his own son, Britannicus. The name Nero, by which he was subsequently known, was added on his adoption. Agrippina was supported in her plan to marry Claudius and for him to adopt Nero by Pallas, a freedman who was her lover, but also one of the emperor's

5. it is clear from the start that she has total control over Nero and she promises both freedmen that if they help her to gain the throne for Nero, they will rule with her: 'If my son reigns, Pallante will reign with Agrippina' (I. IV) and 'If Heaven today 'If my son reigns, Pallante will reign with Agrippina' (I. IV) and 'If
places Nerone on the throne, Narciso will reign with Agrippina' (I. V).

6.As the libretto is in Italian, the names of the characters appear in their Italian versions: Claudio, Nerone, Poppea, Ottone, Pallante, Narciso and Lesbo. However, the Latin versions of the names are used in this article. 
favourites (Suetonius Claudius 28; Tacitus Annals 12.25).7 Agrippina also managed to arrange the marriage between Nero and Octavia, Claudius' daughter, to further strengthen her son's claim to succession (Annals 12.58).

After Claudius' death in 54, allegedly because of poison administered on the instructions of Agrippina, (Annals 12.67-68), Nero was acclaimed as emperor. Claudius' two children, who also feature in the history of Nero's rule, Britannicus and Octavia, are not mentioned in the opera; neither are Burrus and Seneca who, according to the historians, were central figures at the court. Britannicus was murdered on Nero's instructions, when relations with his mother were becoming strained and Agrippina threatened to support Britannicus as the legitimate heir to the throne (Annals 13.14-15). Poppaea did not enter the story until some years later when Nero was already emperor and married to Octavia. Claudius had been dead for some years and played no role in Nero's infatuation with Poppaea. According to Tacitus, Poppaea Sabina was married to an eques, Rufrius Crispinus, but was seduced by Otho and became his wife (Annals 13.45). According to Tacitus, Poppaea was beautiful, but her morals were base. The historian notes that she had everything except an honestum animum, indicating that she lacked a moral compass (Annals 13.45). Otho praised her beauty to his friend, Nero, who then wanted to meet her. Nero fell passionately in love with Poppaea and appointed Otho as governor of Lusitania to get him out of the way (Tacitus Annals 13.46). Poppaea's opposition to Agrippina's control of the emperor is cited as a partial cause for his decision to murder his mother in 59 (Tacitus Annals 14.1). The constant factor in the history and the libretto is that Agrippina opposed Nero's attachment to Poppaea, but for different reasons.

It is clear that Grimani's chronology has moved events around significantly. As a result of this juggling of the historical episodes, it is impossible to situate the action of the opera in a particular year. In the opera, Agrippina mentions Nero's age as 20, but he was emperor at 16 already, after Claudius' death. These are just two more of the counterfactual elements included in the libretto.

One of the most dramatic liberties Grimani took, was to move Claudius' invasion of Britain from 43, before his marriage to Agrippina, to the time when the story of the opera commences. Claudius is away from Rome and this gives Agrippina the chance to plot against him. Events seems to be moving her way, as she receives a letter conveying the news that Claudius has drowned in an accident at sea. That leaves the way clear to assure that Nero can become emperor. Grimani may have found the idea in Suetonius' biography where there are two incidents reported that might have inspired him: the first, in 12.3 , is that a rumour reached Rome that Claudius had been killed while

7.Mottershead (1986:113-114) discusses the influence of freedmen at Claudius court, as Suetonius devotes a chapter (28) to them. He distinguishes Narcissus and court, as Suetonius devotes a chapter (28) to them. He distinguishes Narcissus and
Pallas as being the most powerful. This explains Grimani's choice of making them Pallas as being the most
characters in the opera. travelling to Ostia, and the second, in 17.2, that he nearly drowned in a bad storm at sea while on his way to Britain. Other factors relating to Claudius, mentioned by Suetonius that may have influenced Grimani's plot, are that Claudius was at one stage, so terrified by reports of conspiracies to oust him, that he offered to abdicate (36.1). The cardinal may have taken this idea, although in a totally different context, to present his Claudius as ready to cede to a successor at the end of the opera.

The opening scene of the opera has Agrippina and Nero on stage. A letter has arrived. Agrippina gives it to her son to read. It brings the news that Claudius has died at sea. Agrippina's reaction shows no grief, but a readiness to take advantage of the opportunity. She tells Nero that now the throne is empty, he should be the next occupant. He is 20 years old and ready to rule. Nero is shown to be completely obedient to her. He asks her for instructions, and the plan she outlines to him is typically nuanced. He must hide his pride, go among the people and distribute money. Nero leaves determined to carry out her wishes.

The devious character of Agrippina is revealed in two parallel scenes where she first informs her lover, the freedman Pallas, and then Narcissus, ${ }^{8}$ who is also in love with her, about Claudius' death and her plan to ensure Nero succeeds as emperor. She is aware that the army and the people will appoint the next emperor, but she needs her allies to mingle with the crowds, and when Claudius' death is announced, to proclaim Nero emperor. To each she promises that, when Nero becomes emperor, they will share the power with her. This distorts the historical facts, which show Narcissus as opposed to Agrippina and her plans. In the opera, Agrippina's ability to manipulate others is clearly established from the start, as each of the men she has spoken to, leaves with happy anticipation of what awaits them if they follow her orders. When she is alone on stage, she reveals her true feelings. She is determined to rule and knows that careful planning is necessary to bring this about.

The scene now moves to a square before the Capitol where Nero is distributing money and cultivating the crowds. Both freedmen are doing the same. Each of them reveals their true ambitions in asides. The duplicity of all the characters introduced, is clear. Agrippina now appears and announces the death of Claudius. Her solo is followed by a quartet sung by Pallas, Narcissus, Nero and Agrippina where Nero is proclaimed the new ruler and accepts the office. The trumpet fanfare with which the new emperor is saluted, has hardly subsided when there is a rival fanfare: Lesbo arrives with the news that Claudius is approaching! Otho managed to save him from drowning. The four schemers hide their disappointment with feigned joy. Agrippina manages an assurance in an aside to Nero that he will reign. The audience

8.According to Tacitus (Annals 12.65), Narcissus, one of Claudius' favourites, had become suspicious of Agrippina and her plans and openly supported Britannicus as become suspicious of Agrippina and her plans and openly supported Britannicus as
successor to his father. He had accordingly been dismissed and exiled, and killed successor to his father. He had
shortly after Nero's accession. 
learns that Lesbo's next task is to go and tell Poppaea that Claudius is in love with her.

On the scene, Otho recounts how he saved Claudius and has been named his successor as reward for his brave service. The announcement will be made the next day after the celebration of Claudius' triumph for his conquest of Britain. This news shocks Agrippina, as it overturns her plans. Plenty of asides again reveal the true feelings of jealousy of the four conspirators. Otho, however, reveals to Agrippina that his greatest wish is to marry Poppaea. He prefers that to becoming emperor. Otho's wish to win the woman he loves rather than the seat of power, puts Agrippina's relentless aim to rule into a new perspective. Although she is adept at exploiting the human emotions of others, her own character is dominated by the lust for power. Agrippina's awareness that Claudius is also in love with Poppaea will provide her with a strategy to eliminate Nero's rival to the throne.

Alone on stage Otho rejoices in his good fortune, but he knows that it can change. Otho is a more complex character in his reflection on life, but is also open and honest in contrast to Agrippina's faction and their manoeuvring to get Nero on the throne and through him to rule.

Now Poppaea, alone in her apartment, reveals that Otho, Claudius and Nero have all declared their love for her, but they do not know her true feelings. Lesbo arrives and says that during the storm at sea, Claudius called to her. She pretends to be moved. Agrippina is concealed and hears how Lesbo tells Poppaea that Claudius will come to her tonight.

Alone again, Poppaea confesses that she loves Otho. Agrippina enters and tells Poppaea that Otho has agreed to surrender Poppaea to Claudius provided that he makes him emperor. Agrippina asks Poppaea to persuade Claudius to send Otho into exile. Poppaea cannot believe that Otho has been deceiving her.

When Claudius arrives, he ardently serenades Poppaea, but she warns him that Otho is a threat to him and is also in love with her. She asks him to exile Otho. This is a farcical scene with the emperor passionately trying to make love to Poppaea while she keeps expecting Agrippina to come on the scene to rescue her as they have agreed. An unpleasant aspect of Claudius' character is revealed as he tries in vain to seduce Poppaea. He sings that 'a chaste woman sometimes wants the excuse that violence should be used' (I. XX1.14). This aspect of Claudius' character accords with Suetonius' description of him as savage and bloodthirsty by nature (saevum et sanguinarium natura - 34.1). In the opera, the farce continues as Lesbo runs in to announce that Agrippina is approaching and that Claudius must leave. The lovesick emperor does not want to go and Lesbo and Poppaea have to keep on urging him. When they have got rid of him, Poppaea welcomes Agrippina and expresses her gratitude. Agrippina, at her most devious, assures Poppaea of her love and support in her plan to punish Otho for sacrificing her love to his ambition. This ends the first act. The context has been set and all the characters have been introduced. It is clear that their true desires and ambitions are concealed in their public utterances, but revealed in asides so that the audience is kept aware of their secret goals.

The second act starts with Pallas and Narcissus. They have discovered Agrippina's deception and vow to work together. When Otho enters, they compliment him. The stage fills as Agrippina, Nero and Poppaea arrive to watch Claudius' triumph. ${ }^{9}$ An overt show of devotion between Claudius and Agrippina is undercut by an aside to Poppaea that he loves her. Claudius declares that Otho is a traitor and should be executed, but because he has saved his life, he will spare him. One by one the other characters reject Otho.

Otho is left alone, tormented by his double loss of the throne, and especially, of Poppaea. The scene moves to Poppaea alone in her garden where she confesses that she still loves Otho. She proposes to test him and when he arrives, she pretends to be asleep. When it becomes apparent that he loves her too and that they have both been tricked by Agrippina, Poppaea starts planning her revenge. She accordingly accepts assignations with Claudius and Nero. In the meantime, Agrippina, aware that Pallas and Narcissus know too much and that Otho should not be underestimated, devises new plans. In parallel scenes with each of the freedmen, she gets each to promise to eliminate the other as well as Otho. The reward will be her love and a share in power. In a scene where Claudius hypocritically expresses his love for her, Agrippina persuades him to swear to nominate Nero as his successor to protect himself against Otho. The second act ends with Agrippina once more feeling confident that her aim in making sure her son becomes emperor is on course. She will face any danger to bring that about.

The third act opens with Poppaea's scheme. She conceals Otho behind a curtain in her apartment. When Nero arrives and declares his love, Poppaea warns him that she is afraid Agrippina will come and discover them. Nero must hide and when his mother is gone, she, Poppaea, will prove her love for him. With Nero concealed behind another curtain, the stage is set for Poppaea's revenge. Claudius now arrives and Poppaea reproaches him that he does not really love her. Claudius protests that he has punished Otho, but Poppaea pretends to weep and says it was not Otho but Nero who tried to seduce her. Claudius, at first, does not believe her, but is furious when she reveals Nero in his hiding place. The emperor chases Nero away while Poppaea tells Nero to tell Agrippina that those who seek to deceive are in the end deceived. Nero retorts that Agrippina will get her revenge. Poppaea now fobs off Claudius by saying he must go to pacify Agrippina. Once there is no danger from her, Poppaea will satisfy his love. Claudius sings of his power Io di Roma il Giove sono [I am the Jupiter of Rome (author's own translation)]. Once he has gone, Otho emerges and he and Poppaea joyfully pledge their love to each other.

9.Suetonius notes the splendour with which claudius celebrated his triumph over the victorious campaign in Britain, his only military achievement (12). 
The scene changes to the imperial palace. When Nero asks for his mother's help to protect him from Claudius' anger, she rebukes him for his foolish infatuation which endangers his chance to become emperor. He should renounce any love for Poppaea. Nero obeys. In the meantime, Pallas and Narcissus reveal Agrippina's plots to Claudius. Claudius is confused and does not know who of Agrippina, Nero, Poppaea or Otho are lying. However, when the freedmen tell Claudius that they helped Agrippina to put Nero on the throne when he was believed dead, this confirms what Poppaea had earlier told him. Agrippina and Nero enter and she boldly proclaims that Nero will be emperor today. Claudius' reaction prompts her to confess her plotting to put Nero on the throne, but only when he was away and to preserve the throne for him. The freedmen are impressed by her resilience and cunning, and confirm her account. Claudius says that he is now convinced of her good faith, but she audaciously doubts his, saying that he takes his advice from Poppaea.

Claudius wants to clear the confusion and summons Otho and Poppaea. With all gathered, Claudius causes another shock when he commands Nero to marry Poppaea and names Otho as his successor. Otho refuses, as he loves Poppaea more than power. Claudius then makes everyone happy by saying Otho may have Poppaea as his bride and Nero may succeed him. The opera ends with the descent of Juno to bless the happy union and all ends in reconciliation and love. There is no hint of the dark futures ahead for all of the characters.

This happy ending is a marked contrast to what was typical of the period:

The two decades from 1690 to 1710 saw a new predilection for violence and tragic denouement in Italian opera that produced plots nearer to what we think of as tragedy, and farther from the extravaganzas with happy endings that constituted opera in the last half of the seventeenth century. (Ketterer 2010:139)

From the preceding discussion, it is clear that Grimani and Handel opted to avoid all hints of tragedy and that their reworking of events at the Roman imperial court continued the earlier predilection for extravaganza with a happy ending. In their version there is happiness all round for the main characters. Claudius is content that his 'genius' has provided a solution that pleases everyone: Otho and Poppaea are to have their love find married bliss; Nero is delighted to attain imperial power; and Agrippina has accomplished her ambition of securing the throne for Nero.

\section{Claudius' aria summarises the joyful outcome:}

Let hatreds be at an end, and let Rome applaud this day so long desired, which makes everyone happy and fortunate! By my imperial genius, for the brilliant nuptials of Ottone and Poppea, the patroness Juno is already invited in her magnificent array. Let her now come down, and let Rome place on Nerone's head the crown of laurel! (Sawyer 2013:III.XCVII)
From the description of the action of the opera, it is clear that the Agrippina presented here, preserves the hallmark of a singlemindedness in the pursuit of power that is also evident in the accounts of Suetonius and Tacitus. By altering the chronology, leaving out the trail of corpses and keeping even Claudius alive at the end of the struggle to put Nero on the throne, the libretto enhances Agrippina's inventiveness and resilience. In spite of obstacles and setbacks, she persists in her aim and achieves a happy outcome for all. This turns her from a scheming murderess and murdered mother into a successful manipulator with the ability to secure her ambition without causing any harm. The purpose of the librettist in creating this Agrippina was to make her the main character - a political operator in a satire on the lust for power.

Strohm (1985:5) maintains that Grimani's purpose was to create an 'anti-Bourbon and anti-papal satire, recounting a tale of court intrigue during a palace coup'. He (Strohm (1985:12) further argues that the satire is aimed at Pope Clement XI and his meddling in the machinations, surrounding the succession to the Spanish throne. Strohm (1985:40) ascribes Grimani's hostility to the Pope as caused by losing his influence because of his supporting of the Habsburg claim, while the Pope supported the Bourbons (see also Dean \& Knapp 1987:117). It has further been suggested that the rather clueless Claudius of the opera is meant to be a satirical portrait of the Pope himself, especially in the self-aggrandising aria 'Io di Roma il Giove sono' (Dean \& Knapp 1987:117). While these attempts to link the opera to a particular set of historical circumstances are fascinating, there is no evidence to support such an interpretation. Perhaps support for this view might have been found in the first production, but no contemporary reviews of this survived. Consequently, this intriguing interpretation must remain as educated guesswork.

\section{Conclusion}

It is not necessary to pin the satire of Agrippina to a particular set of historical or political events, to interpret it as a diverting sendup of the stratagems people, who are obsessed with the lust for power, will resort to in order to satisfy their ambitions. The characters who emerge as the most honourable are Otho and Poppaea. Although she is also depicted as full of guile, her purpose is in the cause of true love, while Otho is even prepared to forego his claim to power for the sake of his love. Claudius, Nero and the two freedmen are schemers, but in no way a match for the calculating Agrippina who trumps all, in her successful quest for power. Although her tactics are underhand, the happy ending prevents her from appearing villainous and she becomes rather admirable in her resilience. Undoubtedly, this is a very different woman from the rather tragic figure portrayed by the Roman historians, but the demands of the different genre have allowed Grimani and Handel to create this vibrant heroine - a true prima donna. 


\section{Acknowledgement}

\section{Competing interest}

The author declares that no competing interest exist.

\section{Author contributions}

I declare that I am the sole author of this research article.

\section{Ethical consideration}

This article followed all ethical standards for carrying out research without direct contact with human or animal subjects.

\section{Funding information}

This research received no specific grant from any funding agency in the public, commercial, or not-for-profit sectors.

\section{Data availability statement}

Data sharing is not applicable to this article as no new data were created or analysed in this study.

\section{Disclaimer}

The views and opinions expressed in this article are those of the authors and do not necessarily reflect the official policy or position of any affiliated agency of the authors.

\section{References}

Barrett, A.A., 1996, Agrippina - Sex, power and politics in the early Empire, Yale University Press, New Haven, CT.

Boyle, A.J., 2008, Octavia, attributed to Seneca, Oxford University Press, Oxford.

Dean, W. \& Knapp, J.M., 1987, Handel's operas 1704-1726, Clarendon Press, Oxford.

Dircksen, M.R., 1999, 'Tacitus se uitbeelding van Agrippina Minor', Literator 20(1), 119-139.

Fisbach, F., 2004, Agrippina (DVD recording of Handel's opera), [Film], Dynamic srl, Genoa.

Fisher, C.D. (ed.), 1906, Cornelii Taciti Annalium ab excessu Divi Augusti Libri, Clarendon Press, Oxford.

Ketterer, R.C., 2010, 'Opera Librettos and Greek Tragedy in eighteenth-century Venice', in P. Brown \& S. Ograjensěk, pp. 139-159, Ancient drama for the modern stage, Oxford University Press, Oxford.

Mottershead, J., 1986, Suetonius - Claudius, Bristol Classical Press, Bristol.

Sawyer, J.E. (ed.), 2013, Georg Friedrich Händel Agrippina Opera in Tre Atti HWV 6, Bärenreiter, Kassel.

Strohm, R., 1985, Essays on Handel and Italian Opera, Cambridge University Press, Cambridge. 